\title{
Freudyen Teorideki “Tekinsizlik” Olgusunun Türk Modernleşmesinde Darbeleri Mümkün Kılan Obskürantist ve Self-Oryantalist Tutumlarla İlişkiselliği Üzerinden Okunması
}

\author{
Modernism Reading the "Uncanny" Phenomenon under the Relationality of Obscurantist \\ and Self-Orientalist Approaches Enabling Coup d'état's in Turkish Modernization
}

\section{Burcu KAYA ERDEM ${ }^{\star}$}

Öz

Bireyi, tüm inanç biçimlerinin ötesinde, ait olduğu toplumsal bütünlük dâhilinde güçlü kılan bir bilinç biçimi olarak "öz yeterlik bilinci”, tarihsel izlekte "vesayet demokrasisinin” ötesine geçmenin başarılması ile mümkündür. Öte yandan söz konusu bilinç, bu başarıyla birlikte, yurttaş bireyin kararlarını fiili olarak almakla kalmayıp, bu kararları almaya yetkili olduğu bilinci ve güvenine sahip olmasıyla; "tanıdık bildik olan"ı kendine, kendini ise "tanıdık bildik olan”a ait, güvende ve muvaffak hissetmesiyle mümkündür. Bu düşünce düzleminden hareketle çalışma, Osmanlı İmparatorluğu’ndan Türkiye Cumhuriyeti’ne uzanan tarihsel kesitte, meşru ve sivil yönetime müdahale biçiminde ortaya çıkan "darbe" pratiklerini toplum nezdinde mümkün kılan psikolojik ve sosyolojik zemini algılama amacına yönelik bir okuma denemesidir. $\mathrm{Bu}$ amaca ilişkin olarak, ilgili metinde, “Türk modernleşmesi”, toplum sözleşmesinin tarafı olan ülke yurttaşlarının hak ve özgürlükleri ile kaygı halinin karşısında güven duygusu sağlamlaştırılmış birer birey olma gücünü içselleştirmelerinin önündeki engeller olarak, "tekinsizlik", "vesayet sistemi”, "öz yeterlik bilinci", "self oryantalist modernleşme" ve "obskürantizm" kavramları üzerinden hermenötize edilmiştir. Anahtar Kelimeler: Self-Oryantalist Modernleşme, Obskürantizm, Frustrasyon, Öz Yeterlik, Tekinsizlik.

\begin{abstract}
"Consciousness of self-efficacy", a type of consciousness that renders the individual stronger in terms of social communion that the individual belongs, whilst being beyond of any forms of belief; is only possible, as achieving to pass beyond "tutelage democracy" in the historical path. On the other hand, this

* Doç. Dr., İstanbul Üniversitesi, İletişim Fakültesi, İstanbul, Türkiye, burcu.erdem@istanbul.edu.tr, Orcid ID: 0000-5356-0720
\end{abstract}


very consciousness, along with this success, not only makes decisions de facto for the citizen, but gives a conscience and confidence on competency of making this decision; belonging to one's name "familiar", and "familiar" to one's name, rendering feeling safe and successful a possibility. This study is a reading practice aiming to apprehend the psychological and sociological grounds that make the "coup" practices possible in the eyes of the society emerging as interventions in the legitimate and civilian government throughout the historical period from the Ottoman Empire to the Republic of Turkey. For this purpose, in the relevant text, Turkish modernization - considered as the source of obstacles that prevent the citizens' (who are the parties involved in the social contract) rights and freedoms and also their internalization of the power of becoming an individual with self-confidence - is hermeneutised by the concepts of "eeriness", "tutelage system", "consciousness of self-efficacy", "self-orientalist modernism" and "obscurantism."

Keywords: Self-Orientalist Modernization, Obscurantism, Frustracion, Self-efficacy, Uncanny

\section{Giriş}

$\mathrm{Bu}$ çalışmanın temel sayıltısı, Sigmund Freud'un "tekinsiz” kavramında ifadesini bulan, korku ve kaygı benzeri bir duygunun deneyimlenmesine karşılık gelen sürekli bir ruh halinin, Türk toplumunda "self-oryantalist modernleşme" ve "obskürantist siyasal tutumla" mümkün kılınabildiği ve diri tutulabildiği şeklindedir. Zira darbeler, siyasal mekanizmaları etkileyen bir müdahale olmanın ötesinde toplumsal yapıya yönelik sosyolojik ve psikolojik etkileri olan travmatik bir süreçtir. Bireyin bir tarafı olduğu ve tüm meşruiyet algılarının zemini olan toplum sözleşmesinin, herhangi bir gerekçeyle askıya alınma hali olan "darbe" gibi vesayet dönemlerinde, travma tanımlamasını mümkün kılan psikolojik tezahür "belirsizlikten kaynaklanan kaygı hali” olarak öne çıkmaktadır. Kaygı, kişinin kendini alarm halinde ve sanki sürekli olumsuz bir şey olacakmış gibi bir duygu durumunda hissetmesi durumudur. Bir ülke yurttaşlarını bu kaygı halinden alıp çıkaran ve birey olma vasfını kazandıran şey, bireylerin temel hak ve özgürlüklerini güvence altına almak için, devlet (egemen) gücünde bireyler lehine yapılan sınırlamalar ve bu sinırlamaların net olarak talep edilmesi ve bilinilirliğidir. Jonathan M. Powell ve Clayton L. Thyne (2011) darbeyi "ordunun ya da devlet içindeki siyasi elitlerin örtük ve yasadışı yöntemlerle mevcut hükümeti değiştirmesi” olarak tanımlamaktadır (s. 255). Darbeler gibi, meşru siyasal erkin yetki ve faaliyetlerine ilişkin sınırların, sıklıkla belirsiz hale geldiği süreçlerde, bireyin kendi hak ve özgürlüğüne ilişkin denetimsizlik hali, "kaygı" ve "tekinsizlik" halini mümkün kılan şeydir. Elbette, darbelerin, bireyin ait olduğu toplumsal bütünlüğe ilişkin aidiyet duygusunu, birey olma kabiliyetini zedeleme potansiyelinin yanı sıra, bir toplumda darbe koşullarını defalarca mümkün kılan psiko-sosyal koşulları da gözden kaçırmamak gereklidir. Bu bağlamda çalışmanın arayışı, Türkiyedeki darbeleri potansiyel olarak mümkün kılan koşulları, ordu bürokrasisine "düzen koruyucu”luk vasfi atfeden devlet geleneğinin ötesinde arama/ anlamlandırma çabası yönündedir.

Çalışmanın yöntemi, hermenötik (yorumsamacı) okumadır. Kutsal metinleri yorumlama pratikleriyle ortaya çıkan ve Türkçeye "yorumsama” olarak çevrilen hermenötiği, Hans-Georg Gadamer (1975) şöyle açıklar: "Burada geliştirilen hermenötik, insanî yöntemin anlattıklarının ötesinde gerçekte ne olduğumuzu ve bizi dünya ile ilgili tecrübemizin bütününe bağlayan şeyin ne olduğunu anlama teşebbüsüdür” (s. xiii). Çalışmada, "tekinsiz”, “öz yeterlik”, gibi kavramlar izleğinde, Türk siyasal tutumuna içkin "self-oryantalist modernleşme" ve "obskürantizm” gibi pratikler, 
hermenötik okumaya tabi tutulacaktır. İlgili eylem sırasında, hermenötiğin, dünyadaki temel varlık biçimimizin anlama ve yorumlama olduğu, yorumsamadan bağımsız bilgi bulunmadı̆̆ şeklindeki çıkış noktası temel kabuldür. Bu bağlamda, Türkiye Cumhuriyeti tarihinde defalarca deneyimlenen darbe ve benzeri vesayet rejimlerini, "askeri aygıtın tarihten gelen sosyal ve kurumsal özellikleriyle ve/veya ordu bürokrasisine "düzen koruyucu”"luk vasfı atfeden devlet geleneğine bağlanarak açılama eğilimlerinin” ötesine geçmeye çalışılmaktadır.

Hermeneutik yöntem ile yorumbilgisel döngü denilen şeyin, yani kendimizi metnin öznesinin (yani kendi bağlamı içinde deneyimleyenin) yerine koymamızı ve üretilen şeyin anlamına onun bağlamı çerçevesinde bakma gereksinimine uygun olarak, vesayet sistemine içkin edimler, vesayetin eyleyeni ve eyleneninin psikolojik koşulları ve bağlamı dikkate alınarak okunmaya çalışılacaktır. Ve tüm eleştirel okuma yöntemlerinin ortak paydası olarak, ilk bakışta görünen hâkim okumanın ardındaki sırrın kazınmasına katkı koymaya çalışılacaktır.

\section{Freud'un “Tekinsiz”i Bağlamında Bireyin Kaygı Hali veya “Öz Yeterlik Bilinci”}

Sigmund Freud, 1919 yılında Imago dergisinde yayınlanan “The Uncanny - Unheimlich” (“Tekinsiz”) başlıklı makalesinde, E.T.A. Hofmann’ın "Kum Adam” adlı hikâyesi bağlamında, tekinsizlik halini açıklamaya, tekinsizlik hissinin oluşum koşullarını deşifre etmeye girişir. $\mathrm{Bu}$ duygunun içeriği ve temelinde yer alan, onu var eden durumlar üzerine düşünür:

Almanca bir kelime olan "unheimlich", "sade, basit, vb." anlamına gelen "heimlich" ile "yerli, tanıdık, bildik, vb." anlamına gelen "heimisch" kelimelerinin tam tersini ve dolayısıyla bilinen ve tanıdık olmayan bir olguyu "tekinsiz"i ifade eder. Doğal olarak, yeni ve yabancı olan her şey korkutucu değildir; ilişki tersine çevrilemez. Ancak, yeni olanın kolayca korkutucu ve tekinsiz hale gelebileceğini söyleyebiliriz. (s. 2)

Tekinsizi, dehşet veren bir ruh hali olarak açıklamaya girişen Freud, dehşet, korku ve anksiyete (kaygı) farkları üzerinden açıklamasını derinleştirir. Dehşet (Schreck), korku (Furcht) ve anksiyete (Angst) yanlış biçimde eşanlamlı ifadeler olarak kullanılır; aslında tehlikeyle ilişkileri açısından net bir ayrım yapılabilir. Anksiyete, belli bir tehlikeyi bekleme ya da ona hazırlanma durumunu tanımlar. Korku korkulacak belli bir nesneyi gerektirir. Ancak dehşet, bir insanın hazırlıklı olmadan tehlikeye daldığında içinde bulunduğu duruma verdiği addır; sürpriz etmenini vurgular (Freud, 2002, s. 271). Bir başka deyişle, "tekinsiz"i (unheimlich) türeten kelimelerden biri olan heimlich, Almanca "yerli, evle ilgili, bilindik" gibi anlamları ile tanıdık ve bana ait, bir diğer ifadeyle tekin olanın dinginliğinden; tekinsiz olanın kaygı vericiliğine doğru uzanan çizgide bir anlam yüküne işaret eder. Tam da bu nedenden dolayı,

...tekinsizin işleyiş şekli bastırılmış olanın geri dönmesi, tanıdık olanın yabancı hale gelmesi, onun farklı tezahürlerle kendisini göstermesidir... Tüm bu tekinsiz repertuarına daha fazlası eklenebilir. Ancak hemen hepsinin dayanak noktası bunların etkisinin öznenin anlam dünyasında yalnız ve çaresiz kalmasına neden olmalarıdır. (Ümer, 2017, s. 100) 
Tekinsizliği mümkün kılan iki temel faktör vardır. Birinci faktör, Freud’un eksik bir tanım olduğunu ifade ettiği, "zihinsel belirsizlik", "yabancllık hissi", "ait hissetmeme" faktörü biçiminde açıklanabilir. Zira Jentsh'e göre, "tekinsizlik hissinin oluşumundaki en temel faktör zihinsel belirsizliktir; böylece tekinsiz, daima olması gerektiği yerde olup olmadığının bilinemediği bir şeydir. Çevresi ile aidiyet bağı kuran kimseler, bu ortamdaki nesneler ya da olaylarla ilgili tekinsizlik hissini daha az duyumsayacaklardır" (Jentsh'den akt. Freud, 1919, s. 2).

Tekinsizlik hissini nesnenin niteliğinde değil, algılanışlarında arayan, Jentsh’e yönelik eleştirisiyle Freud, tekinsizliğin oluşumunun sadece zihinsel belirsizliğe bağlanarak açıklanamayacağı iddiasıyla ikinci faktörün altını çizer. Buna göre, tekinsizlik, sadece, zaten bilindiği varsayılan bir şeyin kazandığı yeni kavrayışla ortaya çıkan yabancılık niteliğinden doğan bir yeniden algılanış değil; aynı zamanda, bilinçaltında bastırılanların geri dönmesiyle yüzeye çıkan korku ve kaygıdır. Bir başka deyişle, "bastırılanın geri dönüşü”nü mümkün kılan şeydir. Dolayısıyla mutlak bir son olarak tekinsizlik hissine sebep olan her şey, tüm ortak yönleri ve kökleri ile sunulmuş olur.

Tekinsizin işleyiş şekli bastırılmış olanın geri dönmesi, tanıdık olanın yabancı hale gelmesi, onun farklı tezahürlerle kendisini göstermesidir (Ümer, 2017, s. 99). Bu travmatik tezahür, bir ihtimal olarak hem erkin (yönetenin) hem de yönetilenin bilinçaltında olanın korku ve kaygıların ifadesidir. Öznenin anlam dünyasında yabancılaştıkları karşısındaki çaresizliğinin ifadesidir. Bu güne kadar ait olduğunu düşündüğ̈ ve fakat gelinen noktada aidiyet hissini ve anlam zeminini kaybettiği şeydir. Aidiyet ve anlam zemininin yitimi, bireyin kendi kaderi üzerindeki kontrol hissinin de yitimidir.

Bu bağlamda, tekinsizlik hissi, Mohamed Sid Ahmed'in "Sibernetik Kolonicilik" kuramında duyumsanan "frustrasyon" hissine gönderme yapmaktadır. Sid-Ahmed’e göre bilgisayar ve kitle iletişim teknolojileri tarafından geliştirilen enformasyonu toplama, tasnif etme ve süreçten geçirmede yeni yöntemler gelişmiş ve gelişmemiş dünya arasında yeni bir ilişki türü yarattı. Gelişmiş dünya bu teknolojileri yaratır, gelişmemişler ise bu teknolojilerin etkilerinin pasif alıcılarıdır. $\mathrm{Bu}$ iki dünya arasındaki bu eşit olamayan ilişki günümüzde "sibernetik koloniciliğe" yol açmıştır. Geleneksel sömürgecilik açıkça güç kullandı, mağdurlarda direniş ve savaşma duygusunu besledi. Sibernetik kolonicilik bir çeşit "uzaktan kumanda" ile güç sağlar ve frustrasyon ve umutsuzluk duygularını besler (Ahmed'ten akt. Erdoğan ve Alemdar, 2005, s. 449). Frustrasyon, bireyin kendi kaderi üzerinde kontrol yeterliliğini yitirdiği hissidir. Kontrol ve aidiyet duvarlarının yıkılma halidir. Bireyin, bir yurttaş olarak hak, özgürlük ve beceri potansiyeline dair bilinci (dönüştürme-değiştirme gücü) olarak açıklanabilecek “öz yeterlik” bilincinden sıyrılma halidir. Kendi kaderini, öz yetersizlik algısı nedeniyle, başkalarının insafına bırakmayı olanaklı kılan ruh halidir. Yurttaş olarak öz yeterlik bilincinde etkili olan faktör, bireysel motivasyon değil, yurttaş olarak güç ve etki potansiyelinin bilincinde olmanın verdiği motivasyon hali ve/veya kapasite inanışıdır. Zira, öz yeterlik, "[b]ireyin yapması gereken performans ile kendi kapasitesini karşılaştırıp duruma göre harekete geçmesidir. Bireyin karşılaşmış olduğu güçlüklerde nasıl başarılı olabileceğine ilişkin kendisi hakkındaki inancidır"(Korkmaz, 2009, s. 229). Wood ve Bandura’ya (1989) göre ise öz yeterlik; "bireyin, belirli durumsal amaçlara ulaşmak için gerekli motivasyon, bilişsel kaynaklar ve hareket tarzlarını oluşturma kapasitesine olan inanışları"dır (s. 408). Öz yeterlik seviyesi insanların nasıl hissettiklerini, düşündüklerini, davrandıklarını ve kendilerini motive ettiklerini belirler. Öz yeterliğe ilişkin bu 
inanışlar, bu etkileri 4 farklı süreç aracılığıyla gerçekleştirirler. Bunlar; bilişsel (amaçlar hakkında düşünme), motivasyonel (amaçlar belirleme ve onları gerçekleştirmek üzere çalışma), davranışsal (algılanan başa çıkma yeterlikleri) ve seçimsel (tercih etme ve ortam ve aktiviteler yaratma) süreçlerini içerir (Malone, 2002, s. 11).

Bireyin bilişsel, motivasyonel, davranışsal ve bilişsel düzeyde bir yurttaş olarak mevcut becerilerini eyleme dönüştürmede ne ölçüde başarılı olacağına dair kendine olan inancına sahip olması; ancak frustrasyona uğramamış olması; aidiyet hissi ve anlama zemininin sağlam olması ve materyal/düşünsel düzlemde kendine ve çevresine yabancılaşmamış olmasıyla, yani "tekinsizlik" hissi ile tanışmamış olmasıyla mümkündür. Cogan ve Derricott’a göre (2000) vatandaşlık olgusu, niteliği açısından temel olarak 5 kategoride sınıflandırılmaktadır: Kimlik duygusu (yani aidiyet hissi), bazı hakların kullanılması, ilgili sorumlulukların yerine getirilmesi, kamu işlerine katılım ve ilgi ve temel toplumsal değerleri kabul. Ve birey bunların tamamını, ancak kendi kaderi üzerinde söz sahibi olduğunu, muktedir olduğunu hissettiği koşullarda yapabilir (ss. 2-3).

Bunlardan bir veya birkaçını yerine getirmeyi olanaksız kılan ve/veya yerine getirmeye yönelik öz yeterlik bilincini örseleyen eylem, söylem ya da gelişmeler, yurttaş bireyi tekinsizlik haline, yani frustrasyona sürüklemeye muktedir psikolojik etmenlerdir. Bu etmenlerin sürekliliği, bireyi ilgili ruh durumlarının süreklilik kazanmasına ve bu ruh durumlarını sürdürülebilir kılan gelişmeler karşısında duyarsız ve tepkisiz olmaya, en azından direniş göstermemeye itebilir. Bazı ülkelerde, ilgili ruh halini sürekli hale getirme potansiyeline sahip darbeler ve benzeri vesayet sistemleri, bu minvalde değerlendirilebilir. Zira hak, yetki ve sorumluluklarını devretmeye (bu hakkı kendilerinden daha muktedir olanın kullanmasına) alışmış toplumlar için, frustrasyon ve öz yetersizlik hissi, hak ve sorumluluklarına ve/veya kendi kaderi üzerinde birincil derecede söz sahibi olma hakkına sahip çıkma çabasından daha konforludur. Yurttaş hak ve sorumluluklarına dair kapasite ve motivasyona sahip olmamaktan kaynaklanan kaygı halini kanıksamış, bu hal gündelik yaşamın bir parçası olmuştur.

Kayàya (2013) göre, Osmanlı’nın son döneminde, İttihat ve Terakki ile başlayan vesayet, Cumhuriyet döneminde 1946'ya kadar tek parti vesayeti biçiminde, 1946'dan itibaren de çok partili siyasal hayat üzerinde varlığını sürdürmeyi başarmıştır (s. 491). Özellikle 27 Mayıs 1960 Darbesi sürecinde hazırlanan 1961 Anayasası ile kurumsallaşan vesayet, 1982 Anayasası́nın getirdiği bir kısım anayasal kurumların yardımıyla varlığını pekiştirerek devam ettirmiştir. İktidar, vesayeti tehlikeye girdiği durumlarda, askeri darbeyle varlığını güvence altına almış, askeri darbeler öncesi ortaya çıkan, terör, şiddet ve ekonomik bunalımlar aracılığıyla da gerçekleştirdiği darbeleri ve vesayet düzenini meşrulaştırma çabası içinde olmuştur.

\section{“Düzen Koruyucu Ordu”nun Ötesine Bakmak}

Bireyin söz konusu tarihsel izlekte tüm kenara çekilme ve vesayeti kabullenme süreçlerine, bazı siyasal tutumlar, gerekli psikolojik zemini hazırlayabilir. Türkiye Cumhuriyeti siyasal iletişim tarihinde, kanımızca bunların başında, "kendine özgü modernleşme deneyimi” ve "obskürantizm" gelmektedir. Bu iki siyasal belirlenim, Türk toplumunun kendini ait ve hâkim hissetme olanaklarını 
elinden almış ve topluma kendinden hep daha iyisini bilen bir zümre olduğunu kabullendirmiştir. $\mathrm{Bu}$ halde toplum vesayete açık hale gelmiştir. Öz yeterliğin içkin olduğu bir yurttaş birey olma bilincinin üzerinde yer alan, hikmetinden sual olunmaz ve sorgulanmaz bir hakikate teslim olma sonucunu ortaya çıkarmıştır. Zira yurttaş birey bu süreçte, bilme, hâkim olma, denetleme gücünü ve istencini yitirmiş; zaten bunlara malik olacak bilgiye sahip olmadığını kabul etmiştir. Bu bağlamda tekinsizlikle tanışmış, tanıdık-bildik olanın uğradığı değişim veya tanıdık bildik olanın "makbul olmayan" olarak kabulü, onu, yurttaşlık bilinciyle muktedir olmaktan alıkoyarak büsbütün yabancılaştırmıştır.

$\mathrm{Bu}$ sayltılar, tekrar eden darbelerin gerekçesini ekseriyetle askeri aygıtın tarihten gelen sosyal ve kurumsal özellikleriyle ve/veya ordu bürokrasisine "düzen koruyucu"luk vasfı atfeden devlet geleneğine bağlanarak açıllama eğiliminin ötesindeki arayışların sonucudur. Zira bu sav, (katı kültürlü) patriyarkal bir devlet geleneği anlatısı ile Türkiye’de orduyu mutlak bir güç olarak görme eğiliminin ifadesidir. Oysa dünyada, patiyarkal devlet geleneğine sahip olmakla birlikte ordu bürokrasisine düzen koruyuculuk vasfı atfetmeyen, ordunun koşulsuz sivil kontrole tabi olduğu ülkelerin sayısı azımsanmayacak kadar çoktur. Bu anlatının izlerini modernleşmeci siyaset bilimi anlatılarında aramak bizi daha akılcı çıkarsamalara götürebilir.

Asker-sivil ilişkilerinin kurumsal yapısına odaklanan açıklama biçimi 1960’lı yılların modernleşmeci kuramıyla yakın ilişki halinde gelişmiştir. 1960’lar devrimlerin, bağımsızlık hareketlerinin, iç savaşların ve darbelerin "Üçüncü Dünya" adı verilen coğrafyayı yıkıp yeniden şekillendirdiği bir dönemdir. Bu dönemde yazan araştırmacılar ordunun içinde bulunduğu topluma kıyasla görece istikrarlı ve yerleşik bir kurum olmasını pozitif bir durum olarak değerlendirmektedir. Geç kalkınan ülkelerde, ordu dışındaki diğer kurumların "geri kalmış" olduğu ve bu toplumlarda orduların kalkınmacı, ulusal toplum ve devlet inşası yönündeki pratiklerinin önem taşıdı̆̆ 1 düşünülmektedir (Balta, 2016, s. 52). Bu anlatıya göre, sözü edilen vesayet sisteminin yurttaş bilinci açısından olumsuz bir işlevi yoktur. Zira, ordular devrimci, ilerlemeci, düzen sağlayıcı görevlerini yerine getirip mevcut yönetimde istikrarı, yani rekabetçi bir siyasal düzeni, sağladıktan sonra yönetimi sahiplerine iade edecektir. Bu bağlamda, "bu kurumsal reform tartışmalarındaki temel soru şöyle özetlenebilir: Sivillerin kendilerine yapmasını söylediği şeyi yapabilecek kadar güçlü ama sadece sivillerin kendilerini yetkilendirdiği şeyleri yapacak kadar da tâbi bir ordu nasıl mümkün olur?" (Balta, 2016, s. 53).

Orduya düzen koruyucu vasfı yüklenmesi, darbe metinlerinde de açıkça görülen bir unsurdur. Türkiye'nin sivil siyaset kurumlarının neredeyse her on yilda bir darbeler ve muhtıralarla yeniden dizayn edildiğini ifade ederek başladıkları çalışmalarında Devran ve Özcan (2016) darbe metinlerinde örnekler verirler. Örneğin, 12 Eylül 1980 Darbe metninde "[g]irişilen harekâtın amacı, ülke bütünlüğünü korumak, milli birlik ve beraberliği sağlamak, muhtemel bir iç savaşı ve kardeş kavgasını önlemek, devlet otoritesini ve varlığını yeniden tesis etmek ve demokratik düzenin işlemesine mani olan sebepleri ortadan kaldırmaktır”. Benzer şekilde, 15 Temmuz Darbe Girişimi metninde de "[ç]ağdaş, demokratik, sosyal, laik hukuk ilkelerine dayalı anayasal düzen tesis edilene kadar yurtta sulh konseyi ulusumuz adına her türlü tedbiri alacaktır" ifadeleri yer almaktadır (s. 11, 18). Bu savda öyle ileri gidilmiştir ki, örneğin Schiff’e (2008) göre, ordunun siyasete müdahalesi askerler, yurttaşlar ve siyasiler arasındaki toplumsal uzlaşmayla belirlenmektedir (s. 152). Schiff'in 
iddiasından yola çıkılarak ordu ve siyasiler arasındaki ilişkiselliğin izi, Türkiye Cumhuriyeti siyasi tarihinde "taşıyıcı elitler" veya "siyasi elitler" üzerinden sürülebilir.

Türk iktidar seçkinleri ekonomi, siyasi, askeri ve medya elitleri olmak üzere dört grubun bileşkesinden oluşmaktadır. Söz konusu gruplar, ortak değerler, sosyal ilişkiler ve sahip olunan çıkarlar açısından benzeşmektedir. Ayrıca, Türk iktidar seçkinleri, iktidar, servet ve prestij bakımından toplumdaki en varlıklı bireylerden oluşması yanında; bir toplumun, bir ulusun kaderini belirleme ve muhalifleri ne kadar etkili/güçlü olursa olsun, bütün bunları etkisizleştirip oyunu kendi kurallarına göre oynayabilme ayrıcalığı da onların tekelindedir. Bunların yanında, toplumdaki köşe taşları ve köşe başları da yine onlar tarafından tutulmuştur. Siyasal elitin, toplumu modernize etme işlevini üstlenmiş olması, toplum mühendisliğini de zorunlu kılar. Toplumun kendisinin sağlayamadığı düşünülen dönüşüm, siyasal elitin zorlayıcı düzen kuralları koymasıyla sağlanmaya çalışılır. Artık toplumun, yenilik ve modernliğe taşıyacağına inanılan yeni konulmuş kurallara uymaktan başka bir çıkar yolu da yoktur zaten. Bu durumda ise, siyasal rejim doğal olarak otoriter bir özellik kazanır (Kaya, 2013, s. 498). Sözü edilen seçkin zümrenin modernleşme yolunda attığı adımlar Türk siyasi tarihinde toplumu modernliğe, yeniliğe ve düzene taşıyacağına inanılan bir yolun adımlarıdır, ancak bu adımlar her toplumda aynı hedefe ulaşmamaktadır. Kanımızca, Türkiye Cumhuriyeti’nde "self-oryantalist modernleşme" ve "obskürantizm" şeklinde tezahür eden bu siyasal adımlar, Türk toplumunu vesayet rejimine açık hale getiren, toplumun “öz yeterlik” bilincinin kaybının ve "tekinsizliğin” müsebbiplerinden biridir. Kaya’nın (2013) da belirttiği gibi,

...elit tabaka yeterli ya da yetersiz sebeplerle kendi insanlarının demokratik kurumları işletebileceklerine ve onların bu konudaki kapasitelerine güvenmezler. Bunun sonucu olarak da, hem halkın siyasal demokrasi için zayıf olan bu temayüllerini kuvvetlendirmek, hem de ekonomiyi ve toplumu modernize etmek isterler. Bu da, siyasal elitin, demokrasiyi vesayet altında tutmasının en önemli argümanını oluşturur. Buna göre, siyasal elit açısından, toplum kendi kaderini kendisi tayin edebilecek bir olgunluğa erişmemiştir. Kolayca aldatılabileceğine ve yönlendirilebileceğine inanılan halk, bir yandan kontrol (vesayet) altında tutulurken diğer taraftan uygulanan toplum mühendisliği projeleriyle modernize edilmeye çalışılır. (s. 497)

Bu bağlamda bu çalışma, şahsına münhasır bir modernleşme deneyimi olarak "self-oryantalist modernleşme" ve "obskürantist" siyasal tutumu, yurttaş bireyi kendi kaderini tayin yeterliliğine sahip olmadığına inandırarak tekinsizliğe ve dolayısıyla frustrasyona uğratan psikolojik etkileri açısından ele alacaktır. Çünkü, hem modernleşme hem de obskürantizm yurttaş bireyin öz yetersizlik, gelişmemişlik ve kontrol gereksiniminin sürekli hatırlatılmasıyla yeniden ve yeniden tesisi üzerine kuruludur.

\section{Self-Oryantalist Modernleşme Deneyimi: Self-Oryantalist Modernleşmeye Giden Yolda Modernitenin Öznesi ve Nesnesi Üzerine}

Dünya tarihi, kaçınılması imkânsız ve yapısal bir şekilde dönemin koşullarının belirlediği çeşitli bağlarından kurtulma talebi, direniş, revizyon ve devrimlerle sembolize olmuş bir toplumsal dönüşümler tarihidir. Bu kabulü destekler şekilde, modernleşme kuramcılarının büyük bölümü, 
toplumsal evrimin kaçınılmaz biçimde devamllık gösterdiği ön kabulünden hareketle, bu devamlılığın iki ucundaki toplumlara ilişkin çeşitli tipolojiler oluşturmuşlardır.

Aydınlanma, rasyonalizm ve pozitivizm sacayakları üzerinde yükselen ve Batı toplumlarını karakterize eden modernite de, dünya toplumsal dönüşüm tarihi içinde, düalist epistemolojinin en kesif örneklerine (gelişmiş-gelişmemiş, modern-geleneksel, Doğulu-Batılı) kaynaklık edecek başat dönüşüm noktasının adıdır. Geleneksel olarak adlandırılan feodalitenin yerine kapitalizme içkin değerler, inançlar ve kesin doğruları koyan modernite, kendisini özgün tarihsel koşulları içinde yaratan ve deneyimleyen coğrafya (Batı) tarafından refere edildiğinden, aslında sadece Batı-dışı coğrafyaların sorunudur. Öznesi Batı, nesnesi ise Batı-dışı coğrafyalar olan toplumsal dönüşüm tecrübesinin ifadesidir. Baranın (2013) ifadesiyle,

M.S. 5. yüzyılda Hıristiyanlığı resmen kabul eden Romảnın yeni durumunu, eski Pagan döneminden ayırmak için kullanılan 'Modern' kelimesi, köken olarak Latince 'Modernus'dan gelmektedir. Sonrasında Ortaçağdan, Yeniçağa geçiş yapan Avrupảın yepyeni bir anlayışla yeni baştan doğuşu sürecini ifade etmek için kullanılan 'Modern' kavramı, Batı'nın tarihsel süreç içerisinde kendine has gelişim tecrübesini ifade etmiştir. Modern sözcügüunün, mekân olarak yalnızca 'Avrupa Kıtası'nı kapsaması bunun bir göstergesidir. Modernite bu anlamıyla sadece Batı Avrupa’da, düşünce ve anlayışta beliren yeni bir hayat anlayışı, düşünsel planda yaratılan bir değişim zihniyetidir. (ss. 59-60)

Literatürdeki temel açıklama kaygısı, modernite, modernizm ve modernleşme kavram ve olgularını karşılaştırmalı olarak ele almak şeklindedir. Kanımızca, ilgili olgunun tarihsel kaynakları üzerinden algılanışına ve pratik edilişine bakmak çok daha anlamlı olabilir. Çünkü ancak böylesi bir okumayla, modernleşmenin bugün Batı’nın öznesi Batı-dışı toplumların ise nesnesi olduğu süreksizlik özelliğine sahip bir dönüşüm sürecini ifade ettiği ve tarihsel olarak her daim farklı noktalara yerleştirilebilecek bir "yeni” anlayışını imlediği anlaşılabilir. Modern kelimesi, çağa aitlik ve güncellik içeriğini taşırken, modernizmse yeni olana taraftar ve tutkun olmayı ve büyük oranda eski olana düşman olmayı ifade etmektedir.

Modern kelimesi, Eski Latincedeki modernus kelimesinden türemiştir. Modernus ise "hemen şimdi” anlamına gelen yine Eski Latince modo kelimesinden gelmektedir. Dolayısıyla modern toplum, günümüz toplumlarını, yani yeni olanı işaret etmektedir. Yeni olana ilişkin anlam içeriğiyle modernite terimi, çevresel, ekonomik ve teknik değişimlerin toplumsal ve kültürel düzeydeki tüm etkilerini tanımlamaya dönük bir kavram olarak, toplumsal değişim kuramlarıyla yakından ilişkilidir. Toplumsal değişme ise göreli bir oluşumdur. Kıray’n (1998) belirttiği gibi "Her toplum belirli bir zaman kesitinde, eski yapısından belirli bir düzende uzaklaşmış ve değişmiştir. Daha da önemlisi, bu değişmenin hızı ve temposu zaman içinde aynı değildir” (s. 41). Buradan da anlaşılacağı üzere, modernite, belli bir tarihi dönemde yaşanan büyük ve köklü değişimleri ifade etmekle birlikte, söz konusu tarihsel dönüm noktası tarihin farklı dönemlerinde farklı yerlere yerleştirilebilir.

Tarihin farklı dönemlerine yerleştirilse de, yani ister M.S. 5. yüzyılın sonuna doğru Roma’nın putperestlik geçmişini o sırada Hıristiyanlığın resmen kabul edildiği dönemden ayırmak için (Acar, 2008, s. 60), isterse Avrupa’da yaklaşık olarak 17. yüzyılda ortaya çıkıp zamanla tüm dünyada etkisini 
gösteren toplumsal değerler sistemine kaynaklık eden bir dönüşüm noktası olarak kabul edilsin iki nokta üzerinde uzlaşı katidir: "Geleneksel” olandan kopuşun bireysel, toplumsal ve politik yaşam alanlarının "yeni” yönünde topyekûn dönüşümünün ifadesi ve öznesi Kita Avrupası olan bir olgu oluşu.

Anthony Giddens’a (1990) göre modernite, süreksizlik (discontinuity) özelliğiyle değerlendirilmelidir. Marksist felsefeye dayalı tarihsel materyalist düşünceden hareketle süreksizlik, modernite öncesi ile modernite arasındaki belirgin kırılmayı ve modern toplumsal kurumların birçok bakımdan benzersiz olduklarını anlatmak için kullanılmıştır (s. 4). Bir başka deyişle, geçmişe ait olanın kapsamlı reddi ve geleneksel olandan kati bir kopuşu ifade etmek için süreksizlik ifadesi kullanılmıştır. Bununla birlikte Giddens’ta süreksizlik geleceğe yönelik bir devamlılığı dışlamamakta, yani sürekli sosyal değişmenin, tüm toplumlarda ve sosyal sistemlerde durmadan işleyen ve engellenemeyen bir süreç olduğunu reddetmemektedir. Sözü edilen kırılma, "benzersizlik" gibi kavramların kullanımından anlaşılacağı üzere, modernite veya modernleşme anlatısında logosmerkezci paradigma çerçevesinde referans noktası olarak belirlenen bir hakim öz tanımlanmış, benzersizlik özelliğiyle öne çıkan bu "hakim öz" (referans değer) geleneksel olandan derin bir kırılmayla ayrılmıştır.

Bir diğer deyişle, yeni olana doğru değişme gerçekte istenen yönde evrilme demektir ve bir referans değerin verilmesini içermektedir. Modernite bağlamında bu referans değer veya hakim öz, tarihi bağlamda ortaya koyduğu düşünsel, ekonomik ve siyasal değerler silsilesiyle Kıta Avrupası, yani "Batı"dır. İşte bu nedenle, moderniteyi ve/veya modernleşmeyi okurken, belirlenen referans değerin, onu referans değer yapan tarihsel ve düşünsel faktörlerine değinmek genel eğilimdir. Zira bu faktörler, modernleşmenin özneleri ve nesneleri arasındaki farkı ortaya koyan gelişimsel süreci belgelemektedir.

Modern mantık, bilimsel, siyasal, kültürel ve endüstriyel olmak üzere dört temel devrim sonucunda şekillenmiştir. Bilimsel devrimle dini çevredeki bir doğa anlayışından kendini düzenleyen bir doğaya, doğanın yasalarının belirlenimciliğinden başka bir şeyi dile getirmeyen bir gök mekaniğine geçilir. Artık insanın karşısında belirlenmiş, insanın konumunun çok net olduğu bir dünya ve evren görüşü yoktur. Onun yerini, insanın yasalarını keşfetmek zorunda olduğu bir belirsizlik almıştır. Siyasal devrim, demokrasiyle somutlaşır. İngiltere, Amerika ve Fransa devrimlerinin sonucu olarak demokrasi yönetim biçimlerinden biri olmaktan çıkmış, devletin tek rasyonel biçimi haline gelmiştir. Kültürel devrim, daha yavaş bir gelişme içerisinde ortaya çıkarak kendisini laiklik kavramı içerisinde şekillendirmiştir. Kültürel dönüşüm dini düşüncenin eleştirisi çerçevesinde gelişmiş ve kendisini bir din eleştirisi olarak sunmuştur. Bu durumun varacağı en radikal sonuç, toplumsal yaşamın temellerinin yalnızca rasyonel temeller olabileceğini savunmaktır. Endüstriyel devrim, insanla doğa arasında aracı bir konumda bulunan teknik yapının gittikçe daha büyük bir özerklik kazanması anlamına gelmektedir. İşte sözü edilen tüm bu devrimsel süreçler, arka planında "evrensel” iddiası taşıyan değer yargılarını içeren Batı paradigmasını yaratmıştır. Bu bağlamda modernleşme, farklı düşünürler tarafından sanayileşme, kentleşme, okuryazarlıkta artış, okullaşmış nüfus oranında artış, kitle ve ulaşım araçlarının yaygınlaşması, politizasyon ve/veya toplumsal hareketlenmeyle açıklanmaya çalışılsa da, ilk olarak Batı Avrupa’da ortaya çıkan, sonra Kuzey Amerika’da gelişen 
sosyo-kültürel örgütlenme biçimlerini içermekte ve en az 400 yıllık bir mirasın temsili olan Batı paradigması olarak anlaşılmalıdır. Zira modernleşmeye dair tüm anlatılarda, Batı modelinin evrensel geçerliliği ve tek hedef olarak tarifi neredeyse bir zaruret gibi tekrarlanmaktadır.

Söz gelimi Lerner, modernleşmenin temelinde kentleşmenin yattığı fikrinden hareketle; ...toplumdaki gönüllü kentleşme oranı yüzde yirmi beşi geçtiği zaman artık modern üretim gerekliliğinin ortaya çıkacağını söylemektedir. Böylece modernleşme başlamış olur. Bunu okuryazarlık oranındaki artış izler. Okuryazar oranındaki artış, hem endüstrileşmenin bir sonucu, hem de onun gerçekleşmesi için gerekli bir koşuldur. Bunun ardından kitle haberleşme araçlarının etkisine girme, son aşamada ise siyasal katılım gelmektedir. Lerner bu dört değişken arasında yüksek bir korelasyon bulmuştur. Bunun ardından da modernleşme konusunda Batı modelinin evrensel olarak geçerli olduğunu ileri sürer. Batı'da görülen kentleşme, artan okuryazarlığa, kitle haberleşme araçlarının daha etkili olmasına, artan kitle haberleşme amaçlarının etkisi ile daha geniş ekonomik ve toplumsal katılıma yol açar. Lerner bu süreçlerin, bu sıra ile bütün dünyada geçerli olduğunu belirtir (Akt. Kongar, 2000, ss. 227229).

$\mathrm{Bu}$ ve benzeri anlatılar, kaçınılmaz olarak belirlenen referans noktası üzerinden toplumları modern ve geleneksel (demodern/modern olmayan/gelişmemiş) olarak sınıflamaktadır.

Modernleşme, “ileri oldukları kabul edilen ülke kurumlarının, değerlerinin ve tüketim modellerinin benimsenmesi sürecidir. İlerleme kavramı gibi daima başkasına uyum”u içermektedir. Modernleşmenin, bir toplumun iç dinamiklerinden çok, yönetici elitlerin kendi gerekli gördükleri ve planladıkları bir sosyal değişim sürecini içerdiği düşünülürse, modernleşmenin yanı sıra "Batılılaştırmadan” söz etmek de kaçınılmaz olacaktır. İşte bu nedenle, çalışmanın başında ifade ettiğimiz gibi, modernite veya modernleşme, sadece Batı-dışı (gelişmemiş, modernleşmemiş, yeterince modernleşmemiş ya da geleneksel) toplumların bir sorunudur. Bu noktada önemli olan, özellikle bizimki gibi "bölünük (torn) ülkelerde ${ }^{1 "}$ sorunu açık yüreklilikle tanımlayabilmektir. Bu bağlamda, Batı-dışı modernleşme deneyimlerini araştırarak melez modernleşme pratiklerinin sorunlu yanlarını irdelemeye çabalamak anlamlı bir eleştirel çıkış noktası olabilir. Üstelik iletişim disiplini açısından bu ülkelerin medyaları, melez modernleşme pratiklerinin en kesif örneklerini sunabilmektedir.

Sözü edilen eleştirel ve bir o kadar da açık yürekli yaklaşımı ortaya koyabilmek için önce modernleşmenin bizim anlam haritamızda olduğu gibi salt "Batı tipi modernleşme" ile karşılanamayacak denli kapsamlı olduğunu, farklı modernleşme deneyimlerinin de var olabileceğini anlamak gerekmektedir. Buna rağmen ideal toplum modelini Batı tipi modernleşme olarak seçtiysek,

1 Türkçeye “yırtık ülke” veya "parçalanmış ülke” olarak çevrilen “torn ülke” kavramsallaştırımı Samuel P. Huntington’a ait olup, farklı medeniyetlerin birbirleriyle çarpıştıkları coğrafi bölgelerin, medeniyetler arası fay hatlarını oluşturduğu iddiasına dayanmaktadır. Bu fay hatları sadece ülke sınırlarından değil, zaman zaman ülkelerin içinden de geçebilmekte ve ülkeyi değerler sistemi ve kültürel olarak bölmektedir. İşte bu durumda, yani medeniyet fay hatlarının bir ülkenin içinden geçmesi durumunda o ülke "yırtık ülke” olarak adlandırılır. Huntington'a göre yırtık ülkelerin en derinden yırtılmış olanı, İslam ve Batı medeniyetleri arasında gidip gelen Türkiye’dir. Yine Huntington’a göre, Rusya, Yugoslavya ve Meksika'da diğer torn ülke örnekleridir. Bkz. Huntington, S., P. (1997). Medeniyetler çatışması. M. Yılmaz (Çev.). Ankara: Vadi Yayınları. 
modernite ve/veya modernleşme olgusunun tarihsel ve sosyolojik dinamiklerini iyi okumak, temel dinamikleri deneyimlemeksizin ve içselleştirmeksizin onu salt taklit yoluyla yüklenmenin ağırlı̆̆ altında yaşamanın ne denli güç olduğunu kavramak gereklidir. Aksi halde, moderni, moda veya popüler ile karıştırmak, dahası eklektik/melez modernlik deneyimleri içinde ne gelenekseli, ne de modern olanı hakkıyla yaşayamamak ve insanların hem bilinçleri hem de pratikleri düzeyinde çözümsüz iç çatışmaların başat mekânı olmak kaçınılmazdır. Zira eklektik deneyimler, yurttaş bireyin anlam haritasındaki taşları yerinden oynatmakta, aidiyet bağlarını koparmakta ve tekinsizlik halini perçinlemektedir.

Zira modern, Orta Çağ’’n skolastik anlayışından kurtulup Rönesans ve Aydınlanma ile aklın ürünü olan rasyonel bilim anlayışı ve yönetiminin her alana uygulanmasını ve Tanrı yerine insanı merkeze alan felsefi anlayışı savunur. Batı’nın bu evrelerden geçerek birey ve toplum olarak geldiği seviye de günümüzün modernlik anlayışını somutlaştırmaktadır. Batı toplumlarında çeşitli şartların oluşturduğu ve başlattığı bu değişim ve dönüşüm, geleneksel yapıya karşı koyuşun bir sonucu olduğundan karşılıklı mücadeleler neticesinde ortaya çıkmıştır. Dolayısıyla modernliğin temelinde, geleneksellikle olan çatışma yatmaktadır (Tazegül, 2005, s. 18).

Modernleşme pratiği ve düşüncesi bağlamında, bazı coğrafyaları modernizmin öznesi, bazılarını ise nesnesi kılan şey de işte bu mücadeleler ve çatışmalar ile değer, mantık, örgütlenme biçimleri vb’yi içeren sosyal değişmeyi bazılarının deneyimlemiş, bazılarının ise sadece (moda kabulüyle) taklit etmiş olmasıdır. Bu deneyim farkı aslında, modern kelimesinin "hemen şimdi” veya "günümüzdeki toplum” algısından kaynaklanmaktadır. Çünkü, bir şeyin modern olup olmadığını da,moda (popüler) olup olmadığını da içinde bulunulan zamanın modern veya moda ölçüleri, yani referans değerleri belirlemektedir. Oysa Alain Touraine’nin (1992) Modernliğin Eleştirisi isimli eserinde açıkladığı gibi, modernite salt bir değişim veya olaylar silsilesi değildir. Modernlik, toplumsal yaşamın ekonomi, siyaset, aile, din ve sanat gibi çeşitli parçalarındaki farklılaşmayı içermektedir. Bu farklılaşma modernitenin, bilimsel, siyasal, kültürel ve endüstriyel devrim sacayakları üzerinde oturan devrimci bir süreç olduğu algısını pekiştirmektedir. Farklı uluslar farklı modernleşme pratikleri yaşayabilir, ancak bu noktada eğer Batı tipi modernleşme dışında bir pratik üretilecekse, seçmece Batı değerleri yerine referans değer olarak kendi geleneksel toplum değerlerini belirlemek daha akılcı bir tercih olabilir. Aksi halde, “endüstriyel devrim kalsın da, biz siyasal devrimin bir bölümünü alalım” algısıyla inşa edilecek bir modernleşme deneyimi, yani referans değeri muğlak bir deneyim, sakat doğmuş sayılır ve her daim sorunlara gebedir.

\section{Türk Modernleşmesi ya da Çağdaşlaşma: Bölünük Ülkenin Self-Oryantalist Deneyimi}

Ulus-devletleşme sürecinin temel dinamiği, her ülkenin çeşitli değerler ekseninde saptadığ1 ve ilan ettiği kimlik tanımlarıdır. Batı-dışı toplumlara, kimlik tanımlarının, büyük ölçüde, ulusdevletleşme sürecinin temel dinamiği olarak milliyetçi elitlerce, Batı tipi modernleşmenin taşınmasını kolaylaştıracak şekilde, homojen bir ulusallığı biçimlendirme çabası yönünde yapıldığı gözlenmektedir. Türkiye Cumhuriyeti’nin kurucu felsefesi, tarihsel olarak, acilen kendi "Doğululuğu"nu yok etme ve (laiklik, inkılapçılık, uygarlık ve çağdaşlaşma ilkelerinin gönderme 
yaptığı gibi) Batı tipi modernleşme yolunda homojen bir Türk Ulusu yaratmaktır. Bu bağlamda, toplumun hemen tüm Batı dışı coğrafyalarda olduğu gibi, geleneksel değer ve pratikleri, ilerlemenin önünde bir engel olarak tanımlanmıştır.

Türkiye’nin modernleşme deneyimi kimilerine göre melez, kimilerine göre bölünük, kimilerine göre inorganik, ${ }^{2}$ kimilerine göre taklitçi, kimilerine göre Batıc1, kimilerine göre ise sathi veya yüzeysel bir deneyimdir. Kanımızca ise, self-oryantalist bir deneyim olarak açıklanabilir. Bu deneyim, modernleşmeyi Batılılaşma veya çağdaşlaşma olarak adlandıran ve aslında Batı tipi modernleşme deneyimini tarihsel ve bilişsel değerlerinden sıyırarak belli yönleriyle taklit etmeyi seçen bir yönelimdir. Bu yönelim, "inorganik modernleşme" paradigmasına uygun olarak yukarıdan-aşağıya, tartışılmaksızın ve içselleştirilmeksizin, temel felsefesi sindirilmeksizin politik-tarihsel yükü hafifletilerek yaşama geçirilen, dolayısıyla da entelektüel boyutu derinleşmeyip sığ kalan bir yönelimi ifade etmektedir. Bilişsel boyutu sığ kabuller, yüzeysel kabullerdir ve ancak yüzeysel olarak pratik edilebilir. İlgili konuda, Baran’ın (2013) anlatısı son derece anlamlıdır:

Modernleşme olgusu ile batılılaşma aslında aynı şey değildir. Bu iki kavramın iç içe düşünülmesi kanaatimize göre, yanlış anlayış ve tutumların bir sonucudur. Burada, örnek modelin Batı olması ülkemize has bir durumdur. $\mathrm{Bu}$, modernleşmede tek örneğin Avrupa olacağı anlamına da gelmez. Nitekim bugün artık kabul edilen gerçek, iç gelişme ve dış örneklemelerde her milletin farklı kültürel özelliklere sahip olmalarından dolayı, birbirinden ayrı bir gelişme seyri izliyor olmasıdır. Avrupảnın oluşturduğu modernizm formülü, yine o coğrafyanın yaşadığı modernite ve modernleşmenin bir sonucudur. Zaten tarihî, sosyal ve kültürel gerçeklerini yadsıyarak, sadece doğurduğu sonuçlara göre bir medeniyeti örnek almanın sonucu, kültür çatışması ve modernleşememek olmuştur... Çünkü her medeniyet, kendi gelişim sürecine göre ilerler. Oysa biz Osmanlı'da modernleşmenin faydacı bir bakış açısıyla başlatıldığını, Batı’nın bu amaçla örnek alındığını görüyoruz. Bu bir acil tedbirdir. Çünkü hiçbir devlet, kısa vadeli problemlerine çözüm üretemeden ayakta kalmayı başaramaz. Biz bu çözümlerin, Osmanlı'dan itibaren taklit yoluyla Batı'dan alınarak, gelişmenin yeniden sağlanabileceği ümidiyle hareket edildiğini görmekteyiz. Bu yöntemle Batılılaşmaya çalışmak, modernleşmek anlamına gelmez. (ss. 63-64)

Özetle, Türk modernleşmesiyle aynı anlamda kullanılan çağdaşlaşma kavramı, ancak modernleşme sürecinde idealize edilen bazı tutum ve davranışların kazanılması ve yaşam tarzına tatbiki olarak anlaşılmalı, modernleşmeyi bütünüyle karşılayamayacağı gözden kaçırılmamalıdır. Türk modernleşmesini çağdaşlaşma veya Batıcılaşmaya indirgemenin sonucu, modernleşmeyi tüm düşünsel bağlamından sıyırarak salt Batı medeniyetinin görsel tezahürü olan seküler adab-ı muaşeret

2 Modernleşme ile toplumun tüm alanlarını kapsayacak şekilde sosyal kurum ve insanların yaşam tarzının değişmesi kastedilmektedir. Bu değişimlerin etkinliği, seçilen modernleşme türüne bağlıdır. Uzmanlar iki tür modernleşme ileri sürüyorlar: Organik (birincil, ilk) ve inorganik (ikincil). Tahlilimizin konusu, ülkenin gelişme sürecinin aşaması olan ve geçirilmiş evrimin akışıyla hazırlanan organik modernleşmedir. Bu tür modernleşme, ekonomiden değil kültürden ve toplumsal bilincin değişiminden başlar. Yani diğer değişimler; yaşam biçimi, gelenekler, dünya görüşü ve insanların yönelimlerinin doğal sonucu olarak ortaya çıkıyor. Organik modernleşme aşağıdan, inorganik ise yukarıdan gelir. (Rzayeva, 2005). 
kurallarına takılıp kalmaktır. Türk modernleşmesini, en etkili ve doğru biçimde, İbn Haldun'un Mukaddime'sinde yer alan "mağlubiyet psikolojisi anlatısı” veya taklit (öykünme) kuramıla okumak mümkündür. Zira İbn Haldun, mağlupların düşünüş biçimini tarif ederken, mağlupların galipleri şeklen taklit ettiklerini, çünkü onlara galibiyeti getiren şeyin bu şekil olduğuna inandıklarını anlatmaktadır:

İnsan her zaman kendini yenende bir üstünlük bulunduğuna, ona boyun eğmesi gerektiğine inanır... Bu yanlışlı̆̆a düşünce ve inancını bu yanlışa bağlayınca, artık yenenin tüm yol ve yöntemlerini benimser, ona uymaya çalışır. Bu sadece bir uymadır (iktidar). Ya da Tanrı daha iyi bilir, yenik olan, yenenin gerçekleşen yengisinin yakınlık bağından ya da sertlikten ve baskın gelme özelliğinden değil de, onun tuttuğu yoldan, inançlarından, alışkanlıklarından, yaşama biçim ve çizgisinden ileri geldiğine inandığı için uyar ona. Ki, yenilgiyi açıklama yönünde bu da yanlıştır. Ama bu yanlış öbür yanlışa varır. Bu yanlış nedeniyledir ki, yenik olanı her zaman yenene benzeme çabasında görürsün: Giyiminde-kuşamında, binitindebinişinde, silahında, bunları yapış-kullanış yönteminde ve bunlara verilen biçimlerde... (İbni Haldun, 1977, s. 344)

Türkiye toplumunda devam eden toplumsal değişimi açıklayan en iyi toplum bilimsel kavram, çağdaşlaşma ve/veya medenileşmedir. Çoğu zaman modernleşmeyle eş anlamlı kullanılması üzerinden eleştirilere neden olmaktadır. Çağdaşlaşma olgusu, Batılı bilimciler tarafından farklı biçimlerde ifade edilmiştir. Bu noktada genel yargılar, modernleşmenin, tarımsal üretimden endüstriyel üretime, kapalı köy ekonomisinden dışa dönük kent/pazar ekonomisine, insan/hayvan enerjisinin kullanımından makine enerjisinin kullanımına doğru yapılan geçişlere verilen isim olduğudur. Ancak kimi sosyal bilimciler de toplumun söz konusu alt yapı değişimine paralel olarak ortaya çıkan aydınlanma, pozitivizm ve sekülarizm gibi üst yapısal değişimlerini çağdaşlaşma/ modernleşme olarak değerlendirmişlerdir. Ekonomistler ve mühendisler "altyapı" kategorisini öne çıkararak çağdaşlaşmayı tanımlamalarına karşın, sosyal bilimciler toplumların kültürel ve toplumsal yaşamlarında bireylerin bilinç ve davranışlarında meydana gelen yeni anlayışları çağdaşlaşma olarak benimser.

Çağdaşlaşma, yalnızca bilimsel ve teknik gelişmelerin sonunda ortaya çıkan bir olgu değil aynı zamanda bireylerin ve toplumların bilinçlerinde oluşan yeni farklılaşmaları ve davranışları da dile getiren bir olgudur. Batı'da bu süreç, Rönesans ve Reform çabalarıyla doğan değerler kümesi olarak karşımıza çıkar. Bu süreçle beraber bireysellik, rasyonalite, pozitivizm, sekülarizm gibi anlayışlar çerçevesinde davranan insan ile bu değerler üzerine örgütlenen çağdaş Batı toplumu doğmuştur (Bağcl, 2006, s. 5). Bu bağlamda, farklı modernleşme ve/veya çağdaşlaşma pratiklerinin mümkün olabileceği ifade edilse de, Türk modernleşmesinin çağdaşlaşma kavramıyla karşılanan içeriği, gelişmekte olan tüm toplumların, Batı toplumlarına benzer olarak belirli kademelerden geçecekleri düşüncesiyle oluşturulmuş bir kavramsal ve olgusal bütünlüğe işaret etmektedir. Çağdaş kelimesi son tahlilde, aynı çağda olan demektir. Söz konusu çağın içeriğini veya referans değerinin kim tarafından ve hangi yönde belirlendiği işte bu noktada önem kazanmaktadır. Zira nasıl bir çağa uyacağımız veya çağdaş pratikler içinde hangisini referans değer olarak tanımlayıp, uymayı taahhüt edeceğimiz önemlidir. Türk modernleşmesi bağlamında seçilen referans değer Batılı toplumun çok 
iyi betimlenmiş tarihsel gelişme çizgisidir. Bununla birlikte, söz konusu gelişme çizgisiyle şekillenen değer, mantık, örgütlenme biçimleri ve benzerlerini içeren sosyal değişmenin bilişsel düzeyleri görmezden gelinerek, sadece modernliğin temelini oluşturduğu iddia edilen geleneksellikle olan çatı̧̧ma üzerinden bir toplumsal kimlik inşasına çalışılmıştır.

Peki, bu bütünlüğün yahut self-oryantalizmin konuyla (Türk modernleşmesi veya çağdaşlaşma projesiyle) ilgisi nedir? Self-oryantalist tutum, bilimsel, akılcı ve çağdaş ilerleme nosyonunun ancak Batı tipi modernleşme ile mümkün olduğu algısına gönderme yapan zihniyetin tezahürü olarak, Türkiye gibi Doğulu toplumların, modernite ile oluşturdukları bağlantıyı ifade etmek için kullanılmaktadır. Bezci ve Çiftçi’nin (2012) de ifade ettiği gibi,

Self oryantalizm, modern-ulus devletlerin oluşması sırasında; iradi olarak modernleştirici liderler tarafindan, post-kolonyal dönemde ise modern kolonyalistler ile temas halindeki entelektüeller tarafından kolonyalizm sonrası uygulanan bir politik strateji olarak göze çarpmaktadır. Yani post-kolonyal intelijansiya ve post-kolonyal devlet pratiklerinde oryantalizm içselleştirilmiştir $\mathrm{Bu}$ doğrultuda modernleştirici liderler tarafından inşa edilen self oryantalizm, modernist/batılaşmacı bir içselleştirme süreci sonucunda meydana gelmiştir. (s. 141)

Türkiye Cumhuriyeti’nnin uluslaşma sürecinde, kurucu felsefesinin, tarihsel olarak kendi “Doğululuğu”nu yok etme (oryantalize etme) ve homojen bir Türk Ulusu yaratmak olduğu kabulünden hareketle, iki ana ulusal kimliksel inşa ayağı olduğu söylenebilir: Birincisi, millî egemenlik, millî birlik ve beraberlik gibi milliyetçi söylemlerle homojen bir kimlik tanımı yapmaya dönük olarak etnosentrik; ikincisi ise, bilimsel, akılcı ve çağdaş ilerleme nosyonunun ancak Batı tipi modernleşme (çağdaşlaşma) ile mümkün olduğu algısına gönderme yapan sekülarizm üzerinden Batıcı.

$\mathrm{Bu}$ noktada Türk modernleşmesinin, inorganik modernleşme paradigmasına uygun olarak yukarıdan-aşağıya, entelektüel boyutu derinleşmeyip sığ kalan bir yönelimi ifade ettiği kabulü bizleri, self-oryantalist deneyimlerin başat öznesi olan "entelektüel canlanma"ya veya "taşıııcı elitler"e götürmektedir. Bu algı, modernleşme kuramında modernleşmenin itici gücünün, Batılı tarzda eğitim görmüş kanaat önderleri, aydınlar, vb. olduğu şeklindeki kabule de denk düşmektedir. Zira Bezci ve Çiftci’nin (2012, s. 143) de kapsamlı olarak açıkladıkları gibi, Hindistan örneği üzerinden iradi modern toplumlardaki taşıyıcı elitlerin batıcılık-modernlik enfeksiyonuna tutulmuş oldukları ve bu manada self oryantalizmi bu enfeksiyonun yarattığını iddia eden Jouhkiden (2006, s. 76) hareketle, self-oryantalizmin moderniteye eklemlenme çabaları sonucunda oluştuğunu söylemek mümkündür. Onlara göre, self-oryantalizmi (Türkiye'de dâhil olmak üzere) moderniteye eklemlenme çabalarındaki ülkelerde bedene bürüyen icatçı ve sürdürücü araçlar vardır. İcatçı araçların en önemlilerinden biri de entelektüel canlanma ve taşıyıcı elitlerdir. Entelektüel canlanmada en önemli öğe, bir değer hiyerarşisinin oluşmaya başlaması ve Batılı değerlerin üstünlüğünün kabul edilmesidir. Entelektüel canlanma sırasında, taşıyıcı elitler olarak adlandırılan kesimler Batı'da yaratılan entelektüel araçları benimserler. Burada entelektüel canlanma içinde bulunan aydın, "Batı’nın hegemonyasını kabul etmiş ve Batı́nın gücüne gönüllü olarak teslim olmuş Doğulu özneyi” oluşturmaktadır. Bu doğrultuda toplumsal otantisitenin gerçeklerini yansıtmayan politikalar üretilir ve entelektüel canlanmada rol 
oynayan ve taşıyıcı elit olarak isimlendirilen kesim her halükarda ayrıcalıklı bir özne konumuna gelir (Bezci ve Çiftci, 2012, s. 150).

Cemil Meriç, dönemin taşıyıcı elitleri konusunda en ağır ithamlarda bulunan düşünürlerinden biridir. Ona göre, "Bizim intelijansıyamız Batı’nın yeniçerisidir. Yeniçeri müthiş buluş. Türk, Avrupa’nın çocuğu ile Avrupa'yı vurdu. Ama önce onu hidayete erdirdi. Şimdi Avrupa bizim intelijansıyamızla bizi vuruyor” (akt. Tekin, 2003, s. 59). Bundan sonra önemli olan şey, sözü edilen ayrıcalıklı öznenin ilgili toplumda geleneksel olan ile Batılı değerler arasında ne kadar derin bir yarık açtığı; bu yarı̆̆ın iki yanına kimleri yerleştirdiği ve hepsinden önemlisi de bunu yaparken tarihsel ve bilişsel çerçeveyi neyle ve/veya nasıl çizdiğidir. Kanımızca obskürantist tutum, bu süreçte, Türk modernleşmesinin taşıyıcı elitlerinin en etkili silahı olmuş ve yurttaş bireyin aidiyet ve muktedir olma gücüne gönderme yapan “öz yeterlik bilinci”nin budayıcıları arasında yer almıştır. Söz konusu bilincin yara almasıyla oluşan frustrasyon hali, bireyi her düzeyde vesayet sistemlerine açı hale getirir.

\section{Obskürantist Tutum: Türk Modernleşmesinde Taşıyıcı Elitler ve Obskürantist Tutumun Açmazları}

Yukarıda ifade edildiği üzere, modernite, Rönesans, Reform, Aydınlanma ve endüstrileşme ve uluslaşma ile özgün siyasi yapısını oluşturan Batı tarihsel deneyimini ifade etmektedir. Bu bağlamda modernleşme de Batı-dışı geleneksel coğrafyaların, Batılılaşma yolundaki değişim pratiklerini tanımlamaktadır. İki dinamik arasında önemli bir işlevi yerine getiren kilit rol ise geleneksel toplumların taşıyıcı elitlerine düşmektedir. Batı tipi modernleşme yerine, kimi eleştirmenler tarafından, söz konusu pratiğe, medenileşme, çağdaşlaşma ve/veya modernleştirilme denmesinin nedeni de, taşıyıcı elitlerin tercihleridir. Tazegül'ün (2005) ifadesiyle,

Türk toplumunun, Osmanlı'dan beri varolan modernlik arayışlarını en iyi tanımlayan kavram "modernleştirilmek”tir. Özellikle Cumhuriyetle birlikte modernleştirici bir elitin kendi anlayışlarına uygun olarak çizdiği hedefe, Türk halkını ulaştırma gayreti, Türkiye'deki modernleşmenin tepeden inmeci özelliğinin bir belirtisidir. Batı’da, uzun yıllar alan ve aşama aşama oluşan bir süreç halindeki modernleşme ile, Türkiye'deki, modernleştirici elitin elinde tuttuğu devlet gücünü kullanarak, kendi anlayışı ve çıkarı doğrultusunda içini doldurduğu modernliğin sonucu olan modernleşme deneyimi, modernleştirilme kavramının ifade ettiği kavramı doğrulamaktadır. (s. 219)

Sonradan modernleşen toplumların ortak özelliği olan, azami hızla asgari zamanda ideal modernleşme talebi, Türkiye'deki taşıyıcı elitler için de bir yandan reformların sorgusuz kabullenilmesini olanaklı kılarken, bir yandan da aksaklıkların bahanesi olarak işlevsellik kazanmıştır. Zira aksi halde, modernleşme sürecine eşlik etmesi gereken birey vurgusu, laiklik anlayışı, demokratikleşme ve bireysel özgürlükler noktasındaki eksikliklere kaynaklık eden devletçi ve sınırlandırıcı anlayış çok daha görünür olabilirdi. Kaynar’’n (2012) da belirttiği gibi,

Modernleşme, modernleşme kuramının iddia ettiği gibi, birinden diğerine, geleneksel toplumdan modern topluma bir geçiş, yani iki durağı da net olarak belirlenmiş bir yolculuk 
değildir. Böyle bir yol hikâyesinde kişi, sadece geldiği yere tamamen yabancı bir turistin çaresizliği içindedir, kendisini rehberin kollarına bırakır, modernleşme kuramı da, toplumun erken aydınlarını bu rehberlik pozisyonunda istihdam etmektedir (Kaynar, 2012, ss. 293294).

Modernleşme pratiğinin ülkedeki vuku koşul ve biçimlerinde rehberlik rolü her ne kadar taşıyıcı elitlere verilmiş olsa da, onun içselleştirilme biçim ve düzeyi öngörülemeyecek kadar karmaşık sonuçlar doğurabilir. Ancak bu noktada, iletişimin temel kuralı olan, hedef kitleye göre ileti tasarlama kuralı anımsanmalıdır. Zira modernleştirici taşıyıcı elitlerin geleneksel Türk toplumunda, modernleşme gibi çok boyutlu bir olguyu hangi yönleriyle yerleştirmeye çalıştıkları; nereden başlayıp, nasıl bir gelişme çizgisi tarif veya murat ettikleri bu noktada önem kazanmaktadır.

Self-oryantalist kendi kendini aşağılama tutumu, kendi doğululuğunu yok etme misyonuyla, Türk modernleşmesinin taşıyıcı elitlerince bedene bürünmüş ve "bunlara bu kadarı yeter” ya da "fazlası bol gelir” anlayışıyla tarihsel ve anlam yükünden sıyrılmış, görsel taklit temelinde bir modernleşme deneyimi öngörülmüştür. Böylece, uluslaşma ve Batı tipi modernleşmenin temel dinamiği olacak ulusal kimliğin inşa süreci de daha az çatışmalı ve acısız atlatılacaktır. Oysa modernleşmenin, tarihsel ve bilişsel olarak durağan bir karakteri yoktur. Modernleşme, arka planında evrensel iddiası taşıyan değer yargılarını içeren devrimsel süreçlerden oluşan Batı paradigmasının tezahürüdür. Bu nedenle pek çok düşünür tarafından çatışma, politizasyon ve/veya toplumsal hareketlenme ile açıklanmaya çalışılmıştır.

Modernleşmenin, bir toplumun başlıca tüm alanlarında bilfiil devam eden değişimlere yol açması, çeşitli gruplar arasında, toplumsal sorunların, anlaşmazlıkların ve çatışmaların süregiden ilerleyişini, başkaldırı hareketlerini ve değişime direnişle birlikte düzensizlik ve bozulma süreçlerini de zorunlulukla içermesi anlamına gelmektedir. Düzensizlik ve bozulma böylece modernleşmenin temel bir öğesini oluşturmaktadır. Her modern ve modernleşmekte olan toplum onlarla başa çıkmak zorundadir (Eisenstadt, 2014, s. 35).

Kaçınılmaz olarak düzensizlik, bozulma ve çatışma süreçlerinden süzülen modernleşme olgusunun bu yönü dikkate alındığında, aslında toplumsal kabul ve içselleştirme anlamında ihtiyaç olan süre ve devinimi öngörmek gerekmektedir. Türk modernleşmesinin temel açmazı da budur: Taşı1ıı elitlerce bu süre ve devinim görmezden gelinerek, self-oryantalist bir tutumla modernite, Doğulu yanlarını arkaik ve kimlik dışı olarak işaretlemek suretiyle yok etme anlayışına indirgenmiştir. Dahası bu yok etme çabası, Batı’nın modernleşme maskesinin popüler olduğu ölçüde yüzeysel olan, en basit katmanları kullanılarak sağlanmaya çalışılmıştır. Türk modernleşmesinde temel düsturun, self-oryantalize etmek suretiyle kendi Doğululuğunu tez elden yok etme olduğunu ve yok edilesi doğululuğun karşısında idealize edilen Batı değerlerinin ne ölçüde yüzeysel seçildiğini örnekleyen en derin anlatıları, Besim F. Dellaloğlu’nun (2012) Modernleşmenin Zihniyet Dünyası adlı eserinde bulmak mümkündür. Düşünürün, Türk modernleşmesinin algı dünyasına dair verdiği iki örnek çarpıcıdır:

Benim gençliğimde Beyoğlu kafelerinde Türk kahvesi ya da ince belli bardakta çay istemek taşralılıktı. Bunlar ancak yeşil çuha örtülü kahvelerde bulunurdu. En büyük sorunumuz 
Nescafe’nin sütlü mü yoksa sütsüz mü olacağına karar vermekti. Türk kahvesi evde içilen ve gelenekselliği çağrıştıran bir şeydi. Türkiye modernleşmesi Beyoğlu’nda bize bunları içirmedi. Ne zaman post-modernlik geldi, herkes rahatladı. Göğsümüzü gere gere Türk kahvesi sipariş etmek için postmodern zamanları beklemek zorunda mıydık? (s. 116)

Bin dokuz yüz otuzlarda yıllarca radyoda Türk müziği çalmamıştır. Bin dokuz yüz yetmişlere kadar Türkiye’de Klasik Türk Müziği konservatuvarı yoktu. Sanırım akademik olarak konservatuvara layık olan tek müzik formunun Klasik Batı Müziği olduğu düşünülüyordu. Oysa modern olan, çağdaş olan aynı zamanda klasikten beslenen bir şey. Türkiyede ise modern ve çağdaş klasiğin toptan bir reddi ve çöpe atılması olarak anlaşılmıştır. Batı'da modern klasiğin üstüne geleneğin içinden farklı bir şey çıkarma şeklinde vuku bulmuştur (2012, s. 117).

Dellaloğlu (2012,) "Neyi hatırladığımız ya da unuttuğumuz aslında kim olduğumuzu belirler" demektedir (s. 99). Taşıyıcı elitlerce anlam ve seyir haritası çizilen Türk modernleşmesinin, yüzeysel seçiciliğini, bir başka deyişle toplumca neyi unutup neyi hatırlayacağımızın bilinçli tercihini açıklayan en anlamlı kavram obskürantizmdir. Alatlı’nın ifadesiyle obskürantizm,

...kısaca "bilmesinlercilik", içeriden veya dışarıdan egemen güçlerin kendi hoş görmediği bilgi ve kavramlara, kişilere, topluluklara ilişkin toplumun ana/esas omurgasının bilgi erişimini sistematik olarak kısıtlama çabası. "Obskürantizm”, muğlaklaştırma, müphemleştirme, karartma, üstünü örtme; afazi, Yunanca aphasia'dan. Sözcükleri anlama/kullanma yetisinin kısmi veya tümden kaybı ki, beynin kendisine gelen uyarıları belli bir düzen içinde ve otomatik olarak anlamlandıramadığı durumlarda ortaya çıkar (Akt. Kurtoğlu, 2011, s. 332).

Sosyal bilimler literatüründe çoğu zaman dinci köktencilikle birlikte anılan bu kavram, bilginin belirlenen sınırların ötesinde yayımı ve büyümesine karşı gösterilen tüm çabaları karşılamaktadır. Kitleleri bilinçli olarak bir konu, olgu veya olaylar hususunda cahil bırakma olarak açıklanabilir. Önemli olan ve boyutlarını açıklayabilecek şey ise, hangi fiiliyatlarla yaşama geçirilebileceğidir. Yani seçilen kitleleri, bilinçli olarak karanlığa mahkûm etmenin araçları nelerdir? Tarihsel örneklerine baktığımızda, obskürantizmin siyasal tercihlerle vücuda geldiği zaman ve uzamlarda, sadece bilginin seçili zümrelerin dışına çıkmasının engellenmesiyle sınırlı kalınmadığı̈ görülecektir. Bilgi konusu olan olay veya olguların tarihsel, ekonomik ve/veya politik koşullarından koparılarak, gerçek anlamanın önü tıkanarak anlam yükünün hafifletilmesi; mantığının müphemleştirilmesi de obskürantizmdir.

Bir başka deyişle modernite, tarihsel ve bilişsel olarak dört temel devrimle şekillenen evrimsel süreçler sonunda, evrensellik iddiası taşıyan değer yargılarını içeren Batı paradigmasının ta kendisidir. Yüzlerce yıllık mirasın temsili olan Batı paradigmasını, tarihsel, ekonomik ve/veya politik koşullarından kopararak veya "bu kısmı bize fazla" diyerek benimsemeye ve benimsetmeye çalışmak, obskürantist bir tutumdur. Böylesi bir tutum, Batı-dışı toplumları her daim, Batı değerlerinin gülünç kitle kültürü tüketicilerine dönüştürmüştür.

1930’lu yıllarda, duvarları dökülen ve tam ortasında bir kömür sobası yanan köy okullarında, ayağında ayakkabısı olmayan ilkokul öğrencilerine verilen vals veya mandolin dersleri tam da buna örnektir. Zamanla Batı değerlerinin gülünç tüketicileri yerini kitle kültürü ve popüler kültür 
müptelalarına bırakmış ancak tutumun kapsamı ve adı hiçbir vakit değişmemiştir. Örneğin, bu bağlamda, Batılı kadının birey olarak seküler kimliğini tanıtmaya yönelik üretimlerde, Batılı bilim kadınları yerine "en seksi aktristleri" rol model olarak sunmak da, tarihsel mücadeleler içinden süzülüp gelen bir kimlik kazanım sürecini çarpıtarak karartmaya yani obskürantizme örnektir.

Özetle obskürantizm sadece kitap yasaklayıp, o kitap içeriklerinin bilgisinin belli bir zümre dışına çıkmasını engellemek değildir. Tipkı Türk modernleşmesinde olduğu gibi, yazılı kültür üzerinde yükselen moderniteye öykünürken, toplum tarafından kitapları veya modernitenin anlam ve içerik yükünü okunmayacak hale getirmek, Amerikan tarzı yaşamı modernleşmenin tek göstergesi olarak sunmak ve salık vermek de, obskürantizmin bir örneğidir. Elit zümre ile yurttaş birey arasındaki yarığı kapanmaz bir şekilde açan bu siyasal tutum, öz yeterlik bilincinin oluşmamasının ve tekinsizlik haline yol açan yabancılaşma hissinin nedenleri arasındadır.

\section{Sonuç}

Türkiye’nin siyasi tarihine bağlı modernleşme sürecinde taşıyıcı elitlerin etkisi yadsınamayacak ölçüde büyük olmuştur. Toplumu modernize etme düsturuyla hareket eden siyasal elitler, toplumu yeniliğe ve modernliğe taşıyacak düzenin kurallarını topluma yansıtırken otoriter bir hal almıştır. Zira toplumun kaderinin belirlenmesi, o toplumun bireylerinin eline birakılmamış başka bir deyişle öz yeterlik bilinçlerini kullanmalarına izin verilmemiştir. Türk modernleşmesi, inorganik modernleşme paradigmasına uygun olarak yukarıdan-aşağıya, tartışmaksızın ve içselleştirmeksizin, temel felsefesini sindirilmeksizin politik - tarihsel yükü hafifletilerek yaşama geçirilen; dolayısıyla da, entelektüel boyutu derinleşmeyip sığ kalan bir yönelimi ifade etmektedir. Bilişsel boyutu sı̆̆ kalan Türk modernleşme deneyimi ancak yüzeysel olarak pratik edilebilmiş, bu pratik etme biçim ve yöneliminde de bürokratik vesayet rejimi gereği taşıyıcı elitler önemli bir rol oynamıştır. Öznesinin Batı olduğu bir modernleşme biçimini içselleştirerek self-oryantalist bir modernleşme anlayışı ile gelişen Türk toplumu, Batılı tarzda eğitim görmüş, kanaat önderleri ve aydınlar gibi taşıyıcı elitler vasıtasıyla kendi toplumunun iç dinamiklerinden ziyade ileri oldukları kabul edilen toplumların değerleri ile sosyal değişim yaşamıştır. Türk modernleşmesinin taşıyıcı elitleri, demokrasi olgusunu, modernleşme projesinin kaçınılmaz parçası olarak benimsemiş olmakla birlikte - Batı́da tam tersi bir koşul ilişkisine bağlı olan modernleşme pratiğini - halkın geleneksel olandan mutlak kopuşuna; kendi Doğululuğunu tez elden terk etmeye ve bu yolla sağlanacağı iddia edilen aydınlanma koşuluna bağlamışlardır. Taşıyıcı elitler, toplumu bilinçli olarak benimsedikleri modernleşme anlayışının parametreleri haricindeki parametrelere obskürantist yani "bilmesinlerci” bir tutumla yaklaşmışlar ve bilgiyi örtme ya da ulaşılmamasına izin vermeme gibi yollarla bireyin öz yeterlik bilincinin kaybına yol açmışlardır.

Türk toplumu, deyim yerindeyse Batıllaştırma ile eş değer bir modernleşme süreci geçirmiş ve İslam ve Batı medeniyetleri arasında gidip gelen öznesi kopuk, parçalı bir modernizm deneyimi yaşamıştır. Bu sosyolojik deneyimiyle bölünük ülkeler arasında gösterebileceğimiz Türkiye, psikolojik anlamda ise söz konusu kopukluğu toplumdan bireye geçişte öz yeterlik kaybı ve tekinsizlik deneyimi ile yaşamıştır. Self oryantalist paradigmanın ve obskürantist anlayışın yarattığı, Batı’ya 
karşı iç dinamiklerini arkaik olarak görme biçimi bireylerde tekinsizlik olgusunu içkin kaygı halinin üretilmesine neden olmuştur. Böylece, zihinsel belirsizlik, yabancillk hissi ve ait hissetmeme gibi tekinsizliği var eden temel faktörler ve bireylerin öz yeterlik bilinçlerinden uzaklaşmaları sonucu sahip oldukları frustrasyon, taşıyıcı elitlerin self oryantalist ve obskürantist tutumları aracilığıyla Türk modernleşmesi süresince diri tutulmuştur.

Türk modernleşmesinde, yüzlerce yıllık mirasın temsili olan Batı paradigması, tarihsel, ekonomik ve/veya politik koşullarından kopararak veya "bu kısmı bize fazla" diyerek benimsetilmeye çalışılmıştır. Bunun kaçınılmaz sonucu da, sathi modernleşme deneyimi nedeniyle her daim bastırılmışın geri döneceği endişesiyle tetikte bir bürokrasi ile Batı değerlerinin gülünç kitle kültürü tüketicilerine dönüşmüş bir toplumdur. Zira modernleşme kuramına uygun olarak geleneksel toplum dönemin basınının dışında kalmış, modern ve idealize olan, geleneksel olandan derin bir kırıkla ayrılmış dahası modern olan geleneksel olan için ulaşılmaya çalışılan bir ütopya gibi kurgulanmış ve dönemin basını tarafından öylece sunulmuştur. Sözü edilen ideale ulaşmanın her daim bir hayal olarak kalmasının yaratacağı frustrasyonu engellemek içinse - modernleşmenin yegâne sağlayıcısı olarak sunulan moda ve ekonomi ilişkisi sorgulanarak - ekonomik gücü olmayanların Batılı modern bireye - şekilsel düzeyde - öykünerek de modernleşebileceği yanılsaması yaratılmaktadır. Böylece öykünme, obskürantist tutumun en açık göstergelerinden biri haline gelmekte, yüzylllara dayanan bir birikimi tarihsel ve bilişsel katmanlarını sıyırarak hem sıradanlaştırmakta hem de maskelemektedir. Keza öykünme, modernleşme kuramlarına uygun biçimde, hiçbir vakit aslına yaklaşamayanı imlemektedir. Dahası sathi deneyimler ve obskürantist tutumun yurttaş bireyin psikolojik haritasında bıraktığı izler, topyekûn bir frustrasyonu ve öz yeterlik bilincinde yitimi imlemektedir. Kendi kaderini tayin olgunluğuna erişmediği inancı, yurttaş bireyi, darbe ve benzeri vesayet sistem ve/veya uygulamaları karşısında, ordunun düzen koruyucu sosyal işlevinin darbenin temel nedeni olduğu yanılsamasıyla baş başa bırakmaktadır.

Zira Osmanlı’nın çözülme döneminden başlayarak, değişen Avrupa ve yükselen kapitalizm çağına ayak uydurma adımları olarak modernleşme (Batılılaşma) çabalarının en önemli bileşeni olarak taşıyıcı elitler, bürokratik vesayet rejiminin hem aracı hem sonucu olarak, önemli bir rol oynamıştır. Öznesinin kendi toplumunun iç dinamiklerinden ziyade ileri oldukları kabul edilen toplumların değerleri ile sosyal değişimin motor gücü haline gelen söz konusu zümre, öz yeterliğin devredildiği ilk katmandır. Türk modernleşmesinin ana eğilimleri olarak kabul edilebilecek Batılılaşma, merkezileşme ve otoriteryanizmin işleyişinde de taşıyıcı elitlerin rolü önemlidir. Zira taşıyıcı elitler - toplumun geri kalanının ikna olduğu veya ikna olduğu izlenimi verdiği şekliyle - kendi kaderleri üzerinde söz sahibi olma gücünü devretmeyi kabul ettikleri, - obskürantizm gereği - kendilerinden daha iyi ve daha doğru bilen ve dolayısıyla bu nitelikleriyle de gerektiğinde otoriteryanizmi meşru kılan öznelerdir.

Siyaset bilimi literatüründe yer aldığı biçimiyle, darbenin bir müdahale formu olarak kabul edilirliğini ve dolayısıyla gelişmesini mümkün kılmayan koşullar; demokratik normların kabulü, orduların seçilmişler tarafından denetlemesine olanak sağlayan düzenlemeler, ülkelerin refah oranlarındaki yükseliş ve yurttaş bireyin öz yeterlik bilinci biçiminde sıralanabilir. Zira bir toplumda asker-sivil ilişkileri başta olmak üzere, meşruiyete dayalı tüm toplumsal ilişki biçimlerinin çerçevesini 
çizen şey, bireysel motivasyon değil, yurttaş olarak güç ve etki potansiyelinin bilincinde olmanın verdiği motivasyon hali veya kapasite inanışı olarak tanımlanabilecek “öz yeterlik” bilincidir. Öz yeterlik bilincini törpüleyen, darbeler başta olmak üzere tüm müdahale formları, frustrasyon halinin hem nedeni hem de sonucu olarak, toplumları kendi kaderleri üzerinde söz sahibi olmama halinin çaresiz konforuna mahkûm etme potansiyeli taşımaktadır.

\section{Kaynakça}

Acar K. (2008). Osmanlı ve Rus modernleşmesine dair bazı görüşler. Muhafazakâr Düşünce Geleneği Dergisi, 4(16-17), 59-78.

Bağc1, H. (2006). Kahramanmaraş’ta siyasal değiş̧me: 1950-2004. Yayınlanmamış Yüksek Lisans Tezi. Kahramanmaraş: Kahramanmaraş Sütçü İmam Üniversitesi Sosyal Bilimler Enstitüsü.

Balta, E. (2016). Geçmişten günümüze darbeler, Toplumsal Tarih, (273), 51-55.

Baran M. (2013). Avrupa'da gelişen modernlik ve modernleşme anlayışları ve bu anlayışların Türkiye’ye yansımalarına tarihî sosyolojik açıdan bir bakış. Turkish Studies, 8(11), 55-79.

Bezci, B. ve Çiftci, Y. (2012). Self-orientalization: Modernity within ourselves or internalized modernization. Journal of Academic Inquiries, 7(1), 139-166.

Cogan, J. J. ve Derricott, R. (2000). Citizenship for the 21. century. London: Kogbaan Page.

Dellaloğlu, B. F. (2012). A. H. Tanpınar: Modernleşmenin zihniyet dünyası: Bir Tanpınar fetişizmi. İstanbul: Kapı Yayınları.

Devran, Y. ve Özcan Ö. F. (2016). 1960’tan 2016’ya askeri darbe ve muhtıra metinleri anlamlar, amaçlar, niyetler ve ideolojiler. İnönü Üniversitesi İletişim Fakültesi Elektronik Dergisi. 2(1), 7-20.

Dinçer, M. K. (1998). Kişisel imaj. İstanbul: Alfa Yayınları.

Eisenstadt, S. N. (2007). Modernleşme, başkaldırı ve değiş̧im. U. Coşkun, (Çev.). Ankara: Doğu Batı Yayınları.

Erdoğan, İ. ve Alemdar, K. (2005). Öteki kuram. Ankara: Erk Yayıncılık.

Freud, S. (2002). Metapsikoloji. E. Kapkın ve A. Tekşen Kapkın (Çev.). İstanbul: Payel Yayınları.

Freud, S. (1919). The uncanny. http://web.mit.edu/allanmc/www/freud1.pdf.

Gadamer, H. G. (1975), Truth and method, New York: Continuum.

Giddens, A. (1990). The consequences of modernity. Cambridge: Polity.

İbni Haldun. (1977). Mukaddime I. T. Dursun (Çev.) Ankara: Onur Yayınları.

Jouhki, J. (2006). Imaginig the other orientalism and occidentalism in Tamil European relations in South India, Jyvaskyla: University of Jyvaskyla Press.

Kanl, T. (2006). Medya ve modernleşme: 1945-1960 döneminde National Geographic Dergisi’nde Türkiye’nin Sunumu. Yayınlanmamış Yüksek Lisans Tezi. Ankara: Ankara Üniversitesi Sosyal Bilimler Enstitüsü

Kaya, M. O. (2013). Vesayet demokrasisi ve Türkiye örneği, Afyon Kocatepe Üniversitesi İİBF Dergisi, 15(2), 491538.

Kaynar, H. (2012). Projesiz modernleşme. İstanbul: İstanbul Araştırmaları Enstitüsü Yayınları.

Kıray, M, M. (1998). Değişen toplum yapısı. İstanbul: Bağlam Yayınları.

Kongar, E. (2000). Toplumsal değişme kuramları ve Türkiye gerçeği. İstanbul: Remzi.

Korkmaz, İ. (2009). Sosyal öğrenme kuramı, Yeşilyaprak, B (Ed.). Eğitim Psikolojisi Gelişim-Öğrenme Öğretim içinde (s. 218-238). Ankara: Pegem Akademi.

Kurtoğlu, R. (2011). Türk tarihinde - bürokrasi - siyaset-aydın yabancılaşmasının sonucu: obskürantizmçatışma kültürü ve epistemik çöküş. Sosyoloji Konferansları Dergisi, 44, 325-350. 
Malone, Y. (2002). Social cognitive theory and choice theory: A compatibility analysis. International Journal of Reality Therapy, 22(1), 10-13.

Powell, J. M., Thyne, C. L. (2011). Global instances of coups from 1950 to 2010: A new dataset, Journal of Peace Research, 48(2), 249-259.

Rzayeva, R. (2005). Modernleşme süreci üzerine. Türk Kültürü ve Hacı Bektaş Veli Araştırma Dergisi, (34).

Schiff, R. L. (2008). The military and domestic politics: A concordance theory of civil-military relations, New York: Taylor and Francis e-Library.

Tazegül, M. (2005). Modernleşme sürecinde Türkiye. İstanbul: Babil.

Tekin, M. (2003). Cemil Meriç ile söyleşiler. Konya: Çizgi.

Touraine A. (1992). Modernliğin eleştirisi. H. Tufan (Çev.). İstanbul: Yapı Kredi Yayınları.

Ümer, E. (2017). Tekinsizin estetiği ve sanat yapıtı. SDÜ ART-E Güzel Sanatlar Fakültesi Sanat Dergisi, 10(19), 96-126.

Wood, R. E. ve Bandura, A. (1989). Impact of conceptions of ability on self regulatory mechanisms and complex decision making. Journal of Personality and Social Psychology, 56, 407-415. 